HStud 26 (2012)2, 303-322

DOI: 10.1556/HStud.26.2012.2.9

\title{
PORTRAIT OF THE INVISIBLE. A MEDIOLOGICAL APPROACH TO ZSIGMOND KEMÉNY'S PÁL GYULAI
}

\author{
GERGELY HODJÁK \\ Eötvös Loránd University \\ Budapest, Hungary
}

\begin{abstract}
In terms of poetic composition, Zsigmond Kemény's Pál Gyulai is probably the fanciest Hungarian romantic novel, although this is the first literary work the excellent Transylvanian writer published, in 1847. It could easily win international acclaim among specialists in Romanticism, if it had a translation into one of the widely spoken foreign languages. ${ }^{1}$ This essay attempts to interpret the novel from a primarily mediological point of view, focusing on a small number of scenes, and discussing some relations between certain images, poetic interpretation and ethical issues.
\end{abstract}

Keywords: Zsigmond Kemény, novel, Romanticism, Hungarian literature, hermeneutics, inter-arts

\section{Around a Fictitious Portrait}

In terms of cultural history, the plot of this romantic novel takes place in the late Renaissance Period of Transylvania, roughly between 1581 and 1613 (from the funeral of Voivode Kristóf Báthory to the death of Prince Zsigmond Báthory). In the first chapter of the novel, the elite courtier, Pál Gyulai presents a fictitious portrait of the later prince of Transylvania, the nine-year-old Zsigmond Báthory. The portrait had been ordered by István Báthory, the present Prince of Transylvania, who is also King of Poland (Transylvania and Poland formed a personal union then). Old Báthory wishes to take a good look at his successor-to-be, who lives far from the Polish court. Essentially, the scene draws upon the Hungarian Historia of Johannes Michael Brutus, ${ }^{2}$ which may have been pretty popular in Kemény's political club. ${ }^{3}$ As a matter of fact, the portrait of the prince is in a position of multiple mediations: in the first place, it is supposed to bridge the spatial, geographical gap between Poland and Transylvania; in the second, it is destined to give a 'truthful description' of the young prince's character to the old king. Finally, as for us only some portraits of the adult Zsigmond Báthory are available, the fictitious picture may symbolize the essential absence of the 'self', while, together 
with the later portraits, it may also contribute to a whole 'visual narrative' about the transformation of a personality.

My hypothesis is that the fictitious portrait is the allegory of an ungraspable and mediologically problematic self, being a common problem of the Renaissance Humanism and the Romantic Period. The poetic difficulties in portraying this hypothetical self reveal the structure of the modern subjectivity, i.e., a modern person's 'sojourn' behind (or before) him or herself ('praes-entia'), the constitutive factor of which is its being exposed to the eyes of the others - including somebody's own eyes watching him- or herself in the mirror, or, especially, from a good portrait of his or her own. ${ }^{4}$ Jean-Luc Nancy remarks, concerning this modern paradigm of the self, that the artistic portrait does not recall any specific matter (neither a Hegelian Idea, nor God's confirmatory presence like a sacred icon), but disclosed the constitutive deficiency of a human subject in and for itself - which is evidently the source of personal desires and suffering. ${ }^{5}$ The desirable resemblence of the portrait and the model - being a central problem in Kemény's novel - is actually an illustrative 'différance', or, in other words, the allegory of a hermeneutical void. This modern allegoresis 'rhymes with' the progressive poetic form of the novel (in the spirit of Friedrich Schlegel), ${ }^{6}$ together with the monologues of Pál Gyulai referring back to the moral-theological debates of the Humanist era on 'predestination' and 'free will', ${ }^{7}$ which returns in the German idealism as the central question in the philosophy of history. ${ }^{8}$ Prince Zsigmond and Pál Gyulai, being two contrapuntist characters of the novel in respect of morality, represents also the extreme poles of the Romantic authorship, i.e., a willful steadiness (a will to 'superior values') and an ironic 'capriccio', meanwhile the hermeneutic space between the two opens up a wide range of interpretations for the readers.

In an interesting prelude or introduction to the scene, the narrator, acting the part of somewhat a cultural mediator between the 16th century (time of the plot) and the 19th century (time of his own and of his 'implicit readers'), compares the Renaissance painting with 19 th century photography (i.e., the daguerreotype). ${ }^{9}$ In 'his' opinion, the rise of photography indicates the down-grading of culture, preferring a 'servile imitation' to the 'half-idealization' technique of the Renaissance. The concept of half-idealisation, allegedly being a parameter of the Renaissance painting, may refer to a primarily romantic expectation towards painters, that is, they express the authentic personality of the model by highlighting the most peculiar features in the picture.

The example for 'half-idealisation' (the allegedly Renaissance representation technique) given by the narrator seems to be a pretty obvious, still not 'identifiable' allusion to one the many paintings (maybe a fictitious one also) ${ }^{10}$ visualizing the ancient myth of Diana and Acteon: 
It followed from the principle of 'half-idealization' that for instance the patrician woman who blushed if a knight's gaze wandered to her alabaster shoulders, but who stepped into her bath in front of her male servants naked like the virgin Diana next to the hunting dogs because she didn't consider them beings comparable to her, expressed far more haughtiness on the canvas than she did in the depressing hours that she spent sitting for the artist. (Vol. I. 9.)

Accordingly, the painting is considered to re-present the 'true' personality of the model better than his or her own face, which might as well be a good mask, the organ of play-acting. At this stage of the novel, the narrator seems to be firmly convinced of this very 'truth' of the portait:

And was their not, in this approach, a higher fidelty than in the miserliness of stingy imitation? The portrait of the Transylvanian prince was astonishingly perfect, but in the former sense. (Vol. I. 9.)

This notion of painting was somewhat typical in the early Romantic aesthetics as I will shortly describe it. It must be emphasised that the above expectation is not obvious at all, rather the outcome of certain changes in the history of culture. In Hans Belting's view, for instance, portrait painting had nothing to do with psychological investigations at an early stage. Belting discusses portraits, in contrast to the coat of arms, that is, the historical medium of the aristocrates' 'dynastic I', as a new representation technique for the early bourgeoisie - both media were made by the same guilds and there were hybrid media also (e.g., 'portraits' representing allegories or family features instead of the proper face). The first portraits served clearly a religious function at church donations or family prayers, and only later, as the bourgeois political endeavours interwove with the Humanist philosophy, did become a supplementary medium of linguistic 'I-constructions'. ${ }^{11}$ Now, the Romantic 'image' of portraits seems to have inherited the Humanist tradition in a way.

An elaborated intuitive approach to the reception of images, which sounds the possibility of a direct insight into the model's psychological profile by 'reading' the traces of divine revelation and of the nature, conceived of the early Romanticism. For example, The Disciples At Sais, a fragmented novel by Novalis in 1799, refers to a wonderful cryptography consisting of inextricable letters, which could be the key to human cognition, i.e., the sounding language. ${ }^{12}$ In other words, the 'hieroglpyhical art' of this kind is a visual representation of the Romantic proto language (die Ursprache). ${ }^{13}$ The Outpourings of an Art-Loving Friar (1797), a short aesthetic writing by Wackenroder, also declares the 'hieroglyphical nature' of art, which connects the observer to the 'heavenly phaenomena' intuitively, that is, by re-presenting the true image of the things in the susceptible human heart. ${ }^{14}$ 
A more 'positive' but epistemologically similar approach is attributable to the physiognomy-studies, which assigned face-tipological observations to the traditional forms of behaviours. This paradigm was transplanted to the mainstream of European literature through Goethe, shortly a friend of Johann Kaspar Lavater, the famous physiognomist. Later on, many illustrious writers (including Balzac, Dickens, Poe, Hardy or Oscar Wilde) tended to describe the face as a visual synthesis (or symbol) of the character's socio-cultural milieu and of his or her main drives in life. ${ }^{15}$

So far as I see, Kemény's novel consciously draws upon the remarkable topoi of the early Romanticism (e.g., reading the letters of the souls, which 'shine through' the face, hieroglyphs etc.), but instead of following these often-obscure theories closely, it tries to bring them into an inventive hermeneutical play, that is, a sort of literary jigsaw, which let 'secret' (unconscious) motives in the space of reading.

In presenting the portrait to the king, Pál Gyulai makes positive comments on its workmanship first: "both the depiction of character and the execution demonstrates remarkable skill" (Vol. I. 12.). Apropos of its fancy cadre, Gyulai remarks that "the precious materials competed with the mastery of fashioning, and finally they got subjected to it" (Vol. I. 12. - italics mine). However, his great monologue on the artistic spirit, which allegedly vanquishes even the most precious materials, is suddenly interrupted by the king's cry of pain because of his gouty knees. When Gyulai looks at him with compassion: "Nothing - says the king, being ashamed that the tyranny of the material is about to overcome his spirit" (Vol. I. 13. - italics mine). It is somewhat remarkable that only a few words after Gyulai announced the final triumph of the artistic spirit over the precious materials, the precious material in a different sense (i.e., the king's body) is set against the spirit again.

The mediological confusion even escalates in the following pharagraph. As the proud king discovers that the features of his nephew resembles those of her mother in the portait - who was the offspring of an inferior family - he declares ominously:

I am weak and old... and the picture of him - he shaked his head displeases me. Gyulai, it displeases me. (...) I augur no good for Transylvania. I do not. (Vol. I. 16.)

In aswer to this, Gyulai, being a symbol of immovable fidelity throughout the novel, ${ }^{16}$ delivers a long apology in defence of the child prince, which is, from another point of view, a passionate oration against the portrait, or, to be precise, against the visual representation of human personality in general. Gyulai's oration necessarily rewrites his former positive opinion about the given portrait, while it undermines the previous self-confidence of the narrator, too: 
My dear Lord - Gyulai replied impassionedly. The hand of the artist creates even when it imitates. If it should place two lines a hair's breath closer, the transgression appears in the shift of distance. If it emphasizes a wrinkle, the machination is clear. If the artist's brush is but a shade paler than the tinge of life... lo, the whole legion of dark intentions swarms onto the canvas. Thus the last layer, that completes and cleanses a painting, is not of dead or false substance, but originates in our hearts and shines through our eyes onto the canvas... this affinity. And, Your Majesty, according to old sayings portraiture was invented by a love struck shepherd girl, and in centuries long past was more an instrument of reverence around the funeral pyre. It's ancient purpose, it seems, was more to appease the heart than to deliver up accusatory information regarding some character to the judgment of our acquisitive minds. (...) This picture has many flaws. - Gyulai gazed closely at Torino's work. - Distortions and blunders everywhere. I do not know where, in which spots, or with which compounds. The Italian captivated my mind and put a veil over my eyes. This painting is bad: because Your Majesty does not approve of Zsigmond. But - who would deny it - there are some strokes, there must be, that are flawless copies and strikingly faithful. I would not dare say which, and I cannot choose. For Your Majesty considers the man designated to rule an ill omen. But the ability to read the countenance of a man is no science, it is barely groping, not even that. Perhaps someday our descendants will read the secret writings of the pyramids, the chronicle of Egypt that has been carved into granite, as tirelessly as we read of the wisdom of Salomon and the sentiments of David. Perhaps the stone animals, the cinnamon sealed off from the air, the dappled garments of the mummies someday will tell dumbstruck humanity the stories of one-thousand mute years, must as ink and paper divulge to us the secrets of more recent centuries, the sufferings, joys, deeds, and dreams of muscles that have turned to dust, blood that has vanished into thin air, and paling bones. This is all quite possible. But nature forges its riddles more cunningly than man. This face will never reveal more to our presentiments than misleading information. The letters of the soul are deeds, not strokes. (Vol. I. 16-18.)

Gyulai's oration is self-contradictory. On the one hand, he points out how important function painting serves in human recollection, that is, in recalling (the traces of) the absent. The allusion to the 'love struck shepherd girl' may recall Pliny's myth about the young Corinthian girl (Historia Naturalis, 79 BC) who, being deeply in love with a young man about to depart on a long journey, traced the profile of his shadow as it was thrown upon the wall by a lamp. The young man never returns, and the drawing, in time, becomes a substitute for him in his absence. ${ }^{17}$ But after all, Gyulai's argumentation concludes in the firm belief that the first impressions gained from visual representation (e.g., a portrait) must be put to moral 
investigations, which study the personality in a wider context ("the letters of the soul are deeds, not strokes"). In the meantime, the oration abounds in ethically laden expressions such as "transgression", "machination", "dark intentions", etc.

Discussing the hierarchy of the moral ideas and of different visual representation techniques (including writing and hierographs), it almost seems as if Gyulai got mixed up in his own argumentation. Accordingly, the 'letters of the soul' (the spirit or charachter) get legible by a mediation through different media: they shine through the model's eyes and face, the canvas or the paper, and, finally the receiver's eyes and mind. At every stage of the mediation process distortions may occur since: 1. the prime medium (face) is an extremly elaborated product of Nature, i.e., a quasi-divine entity, also serving as the source of imagination (this is still very much in line with the Romantic tradition); 2 . the secondary medium (the portrait) is the product of an artist, who is inclined to alter 'reality' (i.e., nature) because of his excessive phantasy ("The hand of the artist creates even when it imitates"); 3 . The reciever's mind tends to 'read' the strokes (as letters) according to their own affinities. This argumentation is completely in line with Gyulai's character, who is an ethical person par excellence in the novel. However, it is not unproblematic to imagine a judge who is able to put certain elements of the visual representation aside, including the reconstruction of the case he considers and the telling gestures of the participants in the case under scrutiny.

\section{Mediological Implications}

The traditional primordiality of the language in our culture seems to strike back in the today discourse of cultural issues. Thinking in terms of the 'pictural turn', we are encouraged to derive the language from our more premordial visual experience. ${ }^{18}$ It makes it so much more interesting why W. J. T. Mitchell, a prominent theorist and critic of 'visual culture', who always stresses that the theoretically dissociated senses and signs are unified in real life, and refer to each other in the process of a sensuous and hermeneutical round dance, still insists on maintaining the Romantic privilege of poetry even from a primarily mediological point of view:

The crucial rule of ekphrasis, however, is that the 'other' medium, the visual, graphic, or plastic object, is never made visible or tangible except by way of the medium of language. One might call ekphrasis a form of nesting [one medium appears inside another as its content] without touching or suturing, a kind of action-at-distance between two rigorously separated sensory and semiotic tracks, one that requires completion in the mind of the reader. This is why poetry remains the most subtle, agile master-medium of the sensus communis, 
no matter how many spectacular multimedia inventions are devised to assault our collective sensibilities amalgamate in a more adequate mediological practise. ${ }^{19}$

Now, the question is if Mitchell's expressive description was not influenced by the old humanist reflex as well, which regards the language as, if not literally superior, but a morally favoured medium - a (band)master medium, which is destined to ensure the harmony of the 'less civilised' senses. I can accept this favorization providing it is not regarded as an epistemological categorisation, rather the rhetoric of invitation for a more 'humanistic' way of life.

In contrast with his protagonist, Kemény seems to have regarded painting as a true model for writing. He entered the following words (this time a 'real' ekphrasis) into his diary on 13 August, 1846, that is, during the time he was working on the novel Pál Gyulai:

\begin{abstract}
There were three beautiful landscapes - from foreign lands. One of them made a particularly unusual impression on me. It depicted an evening sky with lightening. The depiction was not strained, and everything in it had been attained with the simplest means. A single stroke indicated that in the middle of the landscape there was a lake, on the waters of which the glimmer of the lightening was shone back. It was as grand in its genre as the scene in one of Sophocles' dramas when the father chides a young Greek leader at length and the girl sighs: father, how you have begrieved me! - and in these few words the girl's love for the boy is revealed. - As a draughtsman I could never use a mere single stroke to create an impression, and as an author I would never hit upon such exquisitely simple phrasing in my dialogues. I am a declamatory man, full of sparkle. ${ }^{20}$
\end{abstract}

In a study on Miklós Wesselényi, a famous politican and orator of the time, Kemény makes a telling remark concerning the state of the contemporary Hungarian language, including his own linguistic skills. He claims there are numerous prominent orators all over the house, but there are only a few of them, who "... would have sought the majestic in the simple, and would have achieved great merits with few tools." ${ }^{\prime 21}$

Presumably, Kemény's 'sparkling' way of writing could own a lot to his affinity toward painting. It is a recurring statement in the reception history that Kemény's language yielded somewhat a reformation to the Hungarian prose. ${ }^{22}$ I try to enlighten my own argumentation better by referring to Gottfried Boehm, the German philosopher and art historian, who considers the flexible and well-proportioned balance between the accurate narration of what is actually taking place in the picture ('facts') and the rhetorical techiques apt for making them 'picturesque' as the linguistic basis for the neat ekphrasis, which is, in this sense, a direct offspring of the ancient rhetorical tradition. ${ }^{23}$ Now, in my view, the prose of 
Kemény goes after the rhetoric traditions as well. It bears a permanent tension between 'action' (generally restricted to laconic statements which accelerate the action) and rather intellectual 'dissections' on social, political or psychological motivations (Kemény was an analytic journalist in 'civil life'). The language of the novel consists of vernacular speech, archaic tenses and syntaxes of the old Transylvanian chronicles, neologisms - I could describe it as a permanent fluctuation between different styles or registers of the present Hungarian language.

But in Pál Gyulai, the revolutionary intellectual deepness of the language seems to be continually undermined by the prolific metaphors, in other words, by the loss of a rhetorical balance - that is why Jenö Péterfy, one of Kemény's first literary critics likened the young Kemény's style to a "smouldering plant" or a "volcanic eruption". ${ }^{24}$ It was probably Miklós Nagy, who first declared, in relation to this very novel, that such a tropological exaggaration could be a symptom of a linguistic crisis. Is it really necessary to write a 10-line passage evoking the "whole" wildlife of the jungle - the monographer asks - in order to express the protagonist's astonishment at the decision of the royal council? ${ }^{25}$

Characterising the Romantic period, Gerhard Neuman and Günter Oesterle speak of a 'mediological crisis', which resulted in regular games played with letters, sounds and tropes inside the semiotics of the language. ${ }^{26}$ Novalis described the poetic language as a transition between painting and music, that is, a flexible capable of overbriding huge sensory (and semiotic) contrasts and great distances. ${ }^{27}$ According to Ernő Kulcsár Szabó, the Romantic language revealed the danger being inherent in an universalist approach to language, which may jeopardise "the heterogeneity principle of the world as the linguistic and cultural basis for individuality". ${ }^{28}$

\section{The Image of the Emperor Nero}

Taking Kemény's outstanding sense for hermeneutical speculations into consideration, ${ }^{29}$ we may not regard the above argumentation as the 'final lesson' of the novel or either that of the protagonist. I consider it as a literary trick provoking reflection on complex philosophical (aesthetic-moral) questions. The implicit purpose of the faithful Gyulai's oration could be reassuring the worried king (and himself) about the successor's capabilities and talents, and thus, indirectly, about the strenght of the feudal order. It is a telling detail that Gyulai plays an important court role in the spectacular funeral scene opening up the narrative of the novel. $\mathrm{He}$ is the priviliged noble vassal, who breaks the lance of the departed prince in two against the wall of the cathedral at Kristóf Báthory's funeral. The powerful symbols in this scene (four silver crosses pointing at the cardinal points forged from the family coat of arms, a black silkflag depicting the squelch of the blason 
by a skeleton, and the resurrection on the other side, etc.) seems to have a duplex denotation as well: on the one hand they show the bereavement of the family, on the other hand they reinforce the feudal order. Accordingly, the power passes on inside the present dynasty; the dead vaivode's son, Zsigmond, takes a seat at the catafalque, supported by the representatives of the church and those of the allied dynasties.

It is also true that the prideful king is right about Zsigmond's dangerous personality, although not because he gets a mystical insight into the soul of the young prince but because of his experience with what we today call 'genetics'. That is, the prince inherited the features of his 'inferior' mother, which is a truth acknowledged by Gyulai as well ("there are some strokes, there must be, that are flawless copies and strikingly faithful"). Still, the protagonist reconsiders the judgement of the king in the name of subtler ethical standards, which is one of the most problematic issues in the novel, as in spite of its 'higher' point of view, Gyulai's scruples lead him to a seemingly logical conclusion to murder Senno, the insignificant artist.

The narrative unfolding the 'real personality' of Gyulai, Zsigmond and the other characters, continually confronts the national-romantic values with the crisis of the same values, the substance with the irony and thus it offers very different readings at the same time.

On one hand, the novel can be interpreted as an ardent criticism against Romantic irony, i.e., a featurless either-or. A mature interpretation of this kind would definitely focus on Prince Zsigmond, who is an ironic charachter par excellence. The central point of his dangerous personality, which unfolds gradually from various points of view in the novel around the image of Emperor Nero, is actually the absence of a center. His main feature is in fact a kind of narcissistic and (consequently) theatrical irony, springing from the lack of a stable identity. As Sopfronia remarks, he falls into melancholy about/for himself from time to time, very much like Søren Kierkegaard's Nero ${ }^{30}$ in Either/or (1841) (as for that, Suetonius' description in The Twelve Caesars may have served as a common model for both):

Because you see, my dear Genga, once every three months the Prince catches a disease, which is cured not by his regular doctor, but the Jesuit. On such occasions, His Royal Highness deigns to fancy, as Nero once did, that in him a great musician of the world is perishing, who could have made the whole Europe dance to his fibre. On such occasions he never makes love or luxuriates, but - reigns. He signs the official letters with his own hands, he himself ties them up with red silk, seals them with three dragon's teeth and hands them to the court postman, for he wants to make the public believe he, who will be overthrown by Boldizsár as he states, was formed as a man whose every fiber was destined to govern, out of a material from which content- 
ment trickles, as naphta from the moorland, for the people. (Vol. I. 201-2.)

According to the following description by the narrator, Zsigmond cultivates a pre-moral or amoral relation with himself, and consequently, with the others - like the extremly elaborated charachters in the first part of the Either/Or (the 'aesthetic phase'):

Does a kind of monomania rule over his highness Zsigmond that is flirtation with the thirst for power without the bleak and steady vigour of ambition, the monomania that strives to keep the world in a state of uncertainty regarding its nature, that issues its historical proclamations for reckoning, that mixes the most natural sentiments with the most affected, until in the end its essence becomes an inexplicable enigma, even to itself? For because of the forced oppositions the delicate ties that bind the ideas of such a man to his worldview, his resolutions to his principles, his desires to his inclinations, his feelings to his temper stretch and slowly break, (...) the harmony of the intellectual world ends, and a raving force in the man who has despaired of himself begins to rule over the furious tumult that rushes from one extreme to the next, seeking the compensation in the bleak delight of variety for the peace he has forever lost. (Vol. II. 90-1.)

Another common point between the Nero-image of Kemény and Kierkegaard is that the irony of the tyrant is somewhat an unconscious one ('shadowgraph' is the key word in Kierkegaard, while in Zsigmond's case, it may have a lot to do with the fact he was taken to see executions as a child in order to acquire the rigor necessary for his reign (II., 90). The immense irony, being a constitutive element of Zsigmond's personality, comes into light when, while taking opium, he speaks to Sofronia, whom he suspects to be a false lover and intends to banish in a little while:

Beautiful Sofronia - the prince said obligingly - I wish to keep the jester to drive the poets and those who pursue original ideas to ruin. What do you imagine, meek damsel, if my faithful people were to get their hands on this smoking nostrum which I hold in my mouth, and which drives away cares more than the strongest drink can exorcise the devil, how rapidly would the already enormous sheaf of ironic notions and witty remarks proliferate? (Vol. II. 158.)

Note the 'jester' or 'buffoon' (the Hungarian word is 'bohóc') plays a primarily ironic poetic function in the plays of Shakespeare or to Schlegel's famous characterization of irony as 'transcendental buffoonery'. ${ }^{31}$

Gyulai's tragic fall during the reign of prince Zsigmond reads, by the same token, as a revenge of Romantic irony on the 'imperative' moral stability demands, 
a kind of irony Kemény must have been familiar with becuase of his strict education. ${ }^{32}$ Certain biographical elements could come under discussion in order to support this reading, The life of love (an autobiographical short novel by Kemény) portrays a severe mother who tries to keep up strict discipline and morality in an ex-noble family reduced to poverty, while the real wish of her child is just lolling on a tree in the garden of a beloved girl. Sámuel Köteles, one of Kemény's favorite teachers in Nagyenyed, was the main interpretor of Kant's moral philosophy in the Transylvania of that time.

Similarly to Prince Zsigmond, the personality of Pál Gyulai has got psychological curiosity, too. In the beginning of the novel the narrator reveals Gyulai got an excellent humanist education in Padua, the 'grounds' of his complex personality and that of his powerful demand for the 'plenitude of life'. He is primarily a high courtier, a 'stateman', who roams in the field of 'historiae' as well. In the meantime he languishes for the love of the mysterious Eleonóra (who conceals a morganatic marriage with Senno) in line with a 'literary seclusion' on his family estate called 'Abafája'. While reading and studying all night, he often contemplates over his faith in typical Hamletian monlogues:

In my mind photographs happen to appear, from time to time, to me as pleading for a shape, a cod, and they call me their murderer because I did not call them into being. (Vol. II. 150.)

The reader is also informed that he took part in a rebellion on the side of his first patron, Gáspár Békessy (who paid for his studies in Padua), but was pardoned because of his honesty by the voivode. As a result, he is under a serious obligation towards the royal family. "Be faithful to Prince Zsigmond with your deeds, your advice, and even in time of sufferings..." (Vol. I. 19.) - this is how his "categorical imperative' would sound like.

However, paradoxically, it is his immense sense of duty which prevents him from balancing the delicate contradictions he encounters both in the anarchy that slowly prevails in Transylvania, and in his personal life. 'Maze' (tömkeleg, téveg) is a recurring key word in the novel, threatening the desired 'balance' (súlyegyen), ${ }^{33}$ while the protagonist's 'fate' continually assaults his faith in providence. He continually alludes to how 'right' history is, at least from a retrospective point of view, in its 'judging' people and events, while the chief feature of the milieu (i.e. the court) Gyulai lives in, is hypocrisy and pretending. The symbol of this is Johannes Michael Brutus, the Italian humanist and chronicler of Transylvania, who, while being a good pen-pal, never appears personally in the novel, even as the studies on History does not play an important role in the life of historical people. Gyulai lives under the spell of poetry and love, while, driven by a 'sense of duty', he gets Senno, the eccentric artist and the secret husband of his 
beloved Eleonóra, executed. While Gyulai feels as if he were predestined, by his gratitude to the royal family, to maintain a consistent and strict charachter in a very chaotic world around him, he does not realize in time that because he caused somone's death unnecessarily, his own life-narrative tends to fall apart as well coupled with the poetic-linguistic structure of the novel. To sum up, I tend to read this as an allegory for a linguistic revenge on the moral imperative, which suppresses the ironic tendencies being inherent in language.

\title{
Unconscious Images
}

As an introduction to the nuanced description of Zsigmond's personality I analysed above, the reader encounters the narrator in the process of recollecting the portrait of the prince again, ${ }^{34}$ which 'he' allegedly studied very attentively:

\begin{abstract}
Many both sought and found in the lines of the youth, who my reader now must certainly suspect is prince Zsigmond, the terrifying signs that immediately enable one to recognize the monster, the despot, the thirst for blood, the Nero of Transylvania. I studied his portrait attentively, and now it appears before my mind's eye in all its tiny details, but I am compelled to confess in all honesty that I could not come to a similar conclusion. Perhaps my views of his character have clouded my vision. (Vol. I. 86.)
\end{abstract}

That is, the traditional mental image of Zsigmond, imprinted by certain historians on collective memory, is considerably altered by the personal hermeneutical effort of the narrator (the part of which is a free imagination in front of his portrait.) So the narrator claims the right to distance his personal opinion from the image of Prince Zsigmond provided by 'real' and official historians, who tried, in a pretty unreflected way, to imprint the image of the Emperor Nero into the minds of the general public instead of creating an own narrative (based on the figure's psychological profile). Somewhat ironically, Pál Gyulai reads Suetonius' The Twelve Caesars in the novel, comparing his own situation to that of Seneca.

As Hans Belting remarks, the question of images is always a question of politics as well: 'iconoclasm' means that people attempt to prevent political forces from imprinting their favourite images (statues, religious icons, electoral placards etc.) on their minds. ${ }^{35}$ Belting traces the apparently troubled and paradoxical attitude toward images within Western culture - hedonistic comsumption on the one hand, and a primarily ethical frame of perception (e.g. the claim of authenticity and of piety) on the other - back to the Reformation period, and the attitude to images in the Old Testament (e.g., the tragical encounter of Moses carrying the Commandments and the people adoring the golden calf at the foot of the Mount 
Sinai). ${ }^{36}$ In Miklós Almási's view, this parallel shows that while the internalized protestant iconoclasm (the one directed against mental images), in line with the distribution of vernacular Bibles, effectively enhanced the believers personal communication with God (that is, a biblical hermeneutics), it could evidently not satisfy the thirst for more emotional, genuine communion, the cult - which is a primarily visual medium. ${ }^{37}$ According to Almási, this 'productive paradox' resulted in the emergence of deeply personal mental images coupled with a largely individualised hermeneutics beyond a collective morality. ${ }^{38}$ Many of Kemény's novels (especially Pál Gyulai, Widow and Daughter and The Fanatics) represent the consequences of such an individual hermeneutics exposed to the danger of fanatism and exploited by political manipulations. ${ }^{39}$ In his monography, Miklós Nagy calls Pál Gyulai to account exactly for this fatalistic disposition, which tends to 'predestine' the protagonist to make a mental image of the political Enemy impersonated by count Boldizsár and the bandmester Senno. ${ }^{40}$

But as the novel clearly indicates, such mental images take a cruel revenge on their owners. The soul of the noble Eleonóra is completly transformed when she sees the fresh corpse of his beloved husband, executed by the oldish mansionguard and double agent Márkházy, who, under the name of Gyulai (represented by his ring), takes a revenge on his pique as a refused lover (in front of the eyes of the portraits of his long-ago lovers). As a result, Eleonóra gradually transforms from a "Iuno who went astray in the labyrinth of wordly love" (Vol. V . 167.) into a vengeful fury, who can easily be manipulated by political forces. She (now a secret agent of the Catholic Habsburg-party) pretends to be in love with Gyulai in order to promote his fall by making Zsigmond jealous. The rather narcissistic monarch, led by the nose by Eleonóra, directs even a sort of theatrical play for Gyulai (squirming between his duty as a statement and his passionate love to Eleonóra) in order to display his 'ownership' of the beautiful Eleonóra, who notes in her diary posteriorly:

\footnotetext{
Incomprehensible was his dissiumulation of this kind, and it made me feel for the first time I also play a role with my heart. (Note on 26 September - Vol. V. 213.)
}

After the successful conspiracy, which overthrows both Gyulai and Zsigmond (and play the country into the hand of the Habsburgs), the broken Eleonóra leads a secluded life haunted by the images of the past and that is, of death. Nevertheless, the terrifying images of the past do not let her alone, and finally, triggered by a call to prepare for a new funeral (namely that of Prince Zsigmond), she will be driven to death by them. As a rather obvious poetic contrapuntist, her fellow nun and intimate friend, Cecil appears as the 'genius of resignation' in the end of the novel, thanks to the fact she managed to keep off the memories of her love-affair with 
Boldizsár. In this sense, the recurring ideal of 'resignation' in Kemény's works seems to be a synonym for the hermeneutical concentration of being-toward-death. The resigned, contemplative characters gain redemption by getting rid of their 'spiritual ballasts', the maniac 'repetition' (Kierkegaard), i.e., the haunting text-images which cannot be integrated into a coherent life narrative. However the resigned individuals of this kind are completely aware of the finiteness of their life time and possibilities, they spend a lot time on processing what they have experienced, by which they avoid the harmful mental images ('idylls or idols'). ${ }^{41}$

\section{In the Wake of the Uncapturable Self}

The novel continually calls the adequate reading of the letters of the soul, that is, the direct accessibility of the self in question, and thus it challenges the self-representation of the humanist and romantic subject. Just when the reader might think he/she has got a key to the bottom of the soul of the characters, the self 'jumps the tracks' suddenly again. In addition to Zsigmond's chameleon-like personality and the incomprehensible murder of the noble, humanist Gyulai, the novel offers many interesting examples of this experience being so decesive in Kemény's world.

The motif of theatrical acting is subtly intertwined with literary mimesis in the novel, which constitutes a certain 'theatre-in-the-theatre'. The dramatic form always belongs to those scenes which represent the life of the Spanish-Italian actors, employed by the Transylvanian court. For example, the first dramatized scene (in Book One, Chapter Two) presents a fancy 'face ball' (a kind of masque), during which everybody shows an inauthentic (literary or political) face. Guzman, the Portuguese 'romance hero' prides himself on great chivalry fights ahead of his fellow actors, but finally it turns out he fought, at the most, in order to seduce a nice maid with his friend. In the meanwhile, various groups of secret agents (those of the Habsburg and the Turkish Empire) mingle with the crowd waiting for the Biblical play to begin. But the scene ends in the very moment the play (about the siege of Jeriko) would actually begin, right before the rise of the curtain... The second dramatised scene (Book Two, Chapter One) is set in a dressing cabin, where the future lovers, Genga (the director of the troup) and Sofronia (the prima donna) are conversing about their wish not to play at life. Just when the love of the two 'soulful' characters, who know the people's falsity very well, would come to life, unexpected events occur, and Sofronia becomes the kind of actor playing one single role forever inspiredly: that of the abandoned lover. In the third dramatised scene (Book Two, Chapter Twelve) the abovementioned Genga argues heavily with Pierro (the clever bajazzo-pickpocket) whether that one is actu- 
ally playacting or not when he states that he was robbed of a politically dangerous letter (namely that of Sofronia) by a stumbling grotesque figure called Gergely diák (a student). The actors do not know Gergely is always playacting in order to carry his 'dark plans' out as a double agent, craving for social rise. When Genga finally unmasks Gergely, and challenges him to a duel, the student, who pretends to be a verdant fencer, kills the enraged Genga with a feint. After all, the novel implicitly confronts the relative sincerity of the Renaissance court actors with the hypocritical pretending of the corrupt courtiers. ${ }^{42}$

'Virtual' and 'real' faces (or masks) come into conflict also in the story of count Boldizsár, the uncle of Prince Zsigmond, who is an admirer of knightly ideas and shows but for long his chivalry has been confined to present spectacular parades and to seduce a naive young actress, Cecil. But from the time he realises that the royal council keeps an eye on him with the purpose of murdering him should he appear as a potential pretender, he is compelled to stay in hiding. Finally (Book Five, Chapter Nine), Boldizsár triumphs secretly (that is, wearing a full face visor) in a tournament, the one originally organised in order to display Prince Zsigmond's heroism (actually his best knight, Mózes Székely fights on behalf of him).

Finally, there is an interesting scene in the novel (Book One, Chapter Six) which describes a secret room in the royal palace furnished by Zsigmond János (the last prince of Transylvania before the reign of the Báthorys) a long time before. The walls of this room are decorated with portraits all around. The narrator explains that all the women's figures in these portraits (without consideration of their ethnotypes) are blond straight-haired females, like Zsigmond János's mother (Queen Isabella), and all the men have long faces with bony and bald foreheads, bushy eyebrows and wide chins like friar György Martinuzzi, her main political enemy. There is also an enigmatic figure in the pictures - probably a potential pretender as the narrator remarks - whose model is unknown either for the beholder of the painting or the reader of the chronicles and historical letters (NB: the narrator tends to get into the role of the audience, a reader or viewer many times in the novel). ${ }^{43}$ The poetic function of this passage is not obvious at all, but a close reading may find some points of interest linking it to the mainstream(s) of the story. The secret room furnished by Zsigmond János now (in the present tense of the novel) belongs to Zsigmond Báthory, who has the same first name. The secret royal council, which deliberates whether to put Prince Zsigmond or his uncle Boldizsár away (the latter considered to be a potential pretender), is set in this secret room as well. The enigmatic figure in the pictures is said to be a potential pretender as well. The metonymic chain of the narration leads me to the conclusion that the secret room could be a symbol of Prince Zsigmond's soul, who is just as afraid of the potential pretender - namely his cousin Boldizsár - as his sometime predecessor used to be. This apprehension or paranoia is evidently a key to under- 
stand the personality of the despotic prince more deeply. Perhaps it is the same paranoia which prompts me to claim that - of course in an indirect and also metonymical-poetic manner - the enigmatic picture of the secret room is again an allegory of the (fictitious) portait of the nine-year-old Zsigmond Báthory, discussed at the beginning of this paper. Thus the adult Prince Zsigmond Báthory would most be afraid of his own (younger) self...

According to Hans Belting, the technical media use symbolique techniques (or 'exchange') to convey imaginary contents (after all, the chameloen-like phenomena we call a 'human self') by extending a living medium, the human body. ${ }^{44}$ So the media have a primarily mimetic function, that is, to 'inscene' the never-ending play of birth, death, love and all the crucial happenings in life, something of which we do not have 'tangible' experience. ${ }^{45}$ Accordingly, the mediological reflection draws our attention back, again and again, to the disillusioning fact that our 'inner self' is not accessible directly, if at all. The self, i.e., the roots of our personal identites are lost in the mists of childhood, the stories of our parents, grandparents, nations - so, after all: in the mystery of time. Obviously, an approach to poesy of this kind is quasi-paradigmatic within the Romantic literature. For example, Novalis 'diagnoses' long before Freud or Jung, that our dreams are able to rip a notable gap on the mysterious curtain of the soul. ${ }^{46}$ In Kierkegaard's Either/or the self is denoted by an illegible letter, the scripts of which tend to grow dim because of the tears coming from the reader's anguished eyes (so the more we try, the less we succeed). ${ }^{47}$ For reading can only provide 'shadowgraphs', not a sharp image of the subject. Now, Kemény's narrator represents the very same experience in Pál Gyulai with the following words:

I firmly believe that every mood of the heart derives from our ideas, but primarily from particles of ideas that are too small and too rapid to take form in words and gain our notice. Thus the seed-bed of our actions, our frame of mind, assumes form amidst tiny influences and impressions that are independent of us, though they arose in us. (Vol. II. 130.)

In his essay Ideas Around the Novel and the Drama, Kemény likens the experience of writing a novel (and that of the uncapturable self) to the subtle, organic transformation of a tree,

the explanation for which is simply the passing of time, is not the stamp of light-mindedness, not a property of transience, but rather a natural process of our character, as are growth, the thickening of the trunk, the formation of bark, and decay in the organic life of the tree. $^{48}$ 
So the organic novel form, like the annual rings of a tree, is the best apt for formulating this experience. Besides, Kemény speaks of a journey on the 'wide, but richly cultivated' plain, which seems unswerving at first sight, but later, in mapping certain details of the journey, the passanger realises the way was rather circuitous and bumpy. ${ }^{49}$ This parable somewhat seems to anticipate Paul Ricoeur's theory of narrative identity. The act of studying a map allegories the act of (biographical) reading, which continually re-figures the vague 'symbolic' impressions we have gained during the journey (that is, our life experience).

Only the perception of this organic plasticity of any personal (or national) identity -"the explanation for which is simply the passing of time" - could constitute the basis for a new approach to stability: the one which admits its radical and vital changeability but still intends to stay credible in the scope of a powerful hermeneutical process ('mapping'). In Ricoeur's terms, the adequate answer of the 'same' (ipse) to the demanding question of the self (idem) - "where are you? can I count on you?" - could only be something like this within the modern world: "here »I« am, the one who always changes". ${ }^{50}$ Accordingly, even though the moral consists of 'roughed strokes' of the relation between the self and the others, it is indispensable for assisting the various cultural formations (family, church, friendship, etc.) by giving culturally accepted guidelines to the unstable individual course of life (just by the dynamic being inherent in simplification). But only in case one has gained personal experience about moral values, will he or she declare of their own motion (beyond the pressure of any categorical imperative): "I try to change in a way which is acceptable for you (or for 'them') as well."

On the other hand, the obvious psychological dangers and difficulties of this acquirement (interiorisation) process we call 'moral education' cannot be left out of consideration any more in the modern world. In other words: the modern sense of life necessitates a permanent mediation between the (Freudian) hermeneutics of desires ('id') and that of the cultural demands (moral values) beyond the possibility of any linguistic shortcut. ${ }^{52}$ For as the example of Pál Gyulai shows clearly, the mediation of the 'I' toward others could jump the track in any step of the process somewhat involuntarily (even with 'good intentions'), the result of which is a sudden loss of balance, and that is, a personal tragedy. ${ }^{53}$

Notes

For the literary quotes, I owe thanks to Thomas Cooper, who wrote his thesis on this novel. Unfortunately, I cannot attach the Hungarian text because of its length. References are given to the respective page numbers of the first edition - Kemény, Zsigmond (1847) Gyulai Pál (Pest: Harleben). A quasi-critical edition is also available today: Kemény, Zsigmond (2011) Gyulai Pál Ed. Kata Dobás (Budapest: Napkút Kiadó). 
2 Brutus, János Mihály Magyar Históriája 1490-1552 (1863-76) Eds Ferencz Toldy, Iván Nagy (Pest: Akadémia).

3 János Barta's Introduction to the novel Kemény, Zsigmond (1967) Gyulai Pál Ed. Gyula Tóth (Budapest: Szépirodalmi), 60.

4 Nancy, Jean-Luc (2010) A portré tekintete (Le regard du portrait) tr. Tamás Seregi (Budapest: Múcsarnok Nonprofit Kft.), 7-20.

5 Mieke Bal uses this term in the sense of a given political-mediological-personal constellation, which came to light through the rise of portrait painting in the western culture: Bal, Mieke (1991), Reading 'Rembrandt': Beyond the Word-Image Opposition (New York and Cambridge: Cambridge University Press), 1-24.

6 Kemény's Gyulai Pál seems to be the first example of the Schlegelian novel form (i.e., an organical synthesis of different genres: prose, drama, lyre, diary, letter etc) in the Hungarian literature. Cf. Szegedy-Maszák, Mihály (2007) Kemény Zsigmond (Bratislava: Kalligram), 86. ff. Thomas Cooper attempts to trail the intertextual relations of the novel in a wider European context. Cooper, Thomas (2002) 'Zsigmond Kemény’s Gyulai Pál: Novel as Subversion of Form' Hungarian Studies, Vol. 16, 29-44.

7 Cf. Erasmus, Rotterdami (2004) A szabad döntésröl tr. Zoltán Rokay (Budapest: Jel Kiadó); Luther, Martin (1996) A szolgai akarat tr. Eszter Csizmadia Jakabné et al. (Sopron: Berzsenyi Dániel Evangélikus Gimnázium); Pomponazzi, Pietro (1967) On God's Foreknowledge and Human Freedom Trans. A. B. Fallico and H. Shapiro in Renaissance Philosophy New York: The Modern Library, 1, 231-80. Pomponazzi's name - in relation to his reasonings on the free will - appears more times in Gyulai Pál.

8 See especially: Schelling, F. W. J. (1861) Philosophie der Kunst. Sämmtliche Werke Hrsg. Karl Schelling and J. G. Cotta (Stuttgart).

9 The narrator or editor, being an interpretor between the different historical ages and cultures, is well-known from certain novels by Walter Scott. Kemény may have followed this literary pattern. See Bényei, Péter (2007) A történelem és a tragikum vonzásában (Debrecen: Kossuth Egyetemi Kiadó), 326 ff.

10 Tiziano, whose name is mentioned in the novel, has got a painting of this myth, but it represents only one dog and maid-servants. Nevertheless, in a posterior novel of Kemény titled Swirls of the heart, Tiziano's painting (The three ages of man) serves an important poetic function indeed. Cf. Bényei, Péter (1997) 'A szerelem élete: A Kemény-elbeszélések világképe és poétikája' in Zsigmond Kemény Kisregények és elbeszélések, Ed. Péter Bényei (Debrecen: Kossuth Egyetemi Kiadó), 262-6.

11 Belting, Hans (2011) An Anthropology of Images tr. Thomas Dunlap (Princeton, NJ: Princeton University Press), 62-83.

12 "In ihnen ahndet man desn Schlüssel dieser Wunderschrift, die Sprachlere derselben, allein die Ahndung will sich selbst in keine feste Formen fügen, und scheint kein höherer Schlüssel werden zu vollen.” Novalis (Friedrich von Hardenberg) (1969) Die Lehrlinge zu Sais. Werke Hrgs. Gerhard Schulz (München: C. H. Beck), 95.

13 "Die erste Kunst ist Hieroglyphistik" Ibid., 392. Discussed in detail by Orosz, Magdolna (2004) ‘A nyelv elégtelensége: Képleírás a német romantikában’ Jelenkor, Nos 7-8, 765-79.

14 Wackenroder, Wilhelm Heinrich (1991) Sämtliche Werke und Briefe: Historisch-kritische Ausgabe I. Hrsg. Silvio Vietta, Richard Littlejohns (Heidelberg: Universitätsverlag), 98 ff.

15 Cf. Porter, Roy (2003) Marginalized Practices (Cambridge: Cambridge University Press), The Cambridge History of Science IV, 495-7; The Faces of Physiognomy: Interdisciplinary Approaches to Johann Caspar Lavaterm (1993) Ed. Ellis Shookman (Columbia, SC: Camden House). 
16 In respect of this main characteristic of Gyulai an observation of Ernő Kulcsár Szabó could be of importance: "az én rögzíthetetlenségének nevezetes romantikus tapasztalata ugyan mindig a szubjektum belső végtelenségét, stabilizálhatatlanságát és sokféleségét hangsúlyozza, (...) de ezt a dichotóm struktúrát végül mégsem a szubjektum temporalizálódásának helyeként érti, hanem a sokféleségen való értékjellegü felülkereskedés identitásteremtő feltételét látja benne. «A legtökéletesebb ember - írja Novalis - összes változásaival együtt uralja konstitúcióját.»" Ernő Kulcsár Szabó (2001) ‘A fragmentum néhány kérdése a nyelviség horizontváltásában’ in Mihály Szegedy-Maszák and Péter Hajdu (eds) Romantika: Világkép, müvészet, irodalom (Budapest: Osiris), 42.

17 The mediological approach behind this myth seems to be somewhat suprisingly up-to-date to me. In Hans Belting's view, the anthropological function of images originates from the essential human desire (historically that of the prehistoric tribes) to 're-animate' the dead, namely a departed person's spirit (the trace or absence of his place within the tribe) by embodying it in a visual medium. For example, a ritual artefact of the Neolotic era represents a human face made of a skull (for the head), of clay (for the skin), and shells (for the eyes). Cf. Belting, Hans (2005) 'Image, Medium, Body: A New Approach to Iconology' Critical Inquiry, Vol. 31, No. $2,307-8$.

18 Cf. Bredekamp, Horst (2004) 'Drehmonte - Merkmale und Ansprüche des iconic turn' in Hubert Burda and Christa Maar (Hrsg.) Iconic turn. Die neue Macht der Bilder (Köln: DuMont) 15-27; Sauerländer, Willibald (2004) 'Iconic turn? Eine Bitte um Ikonoklasmus' Ibid., 407-27. The 'pictural turn' tends to turn on if, from a psychoanalistic point of view, one derives visuality from the baby's smelling and touching the breast (and so on).

19 Mitchell, W. J. T. (2007) 'There are No Visual Media' in Oliver Grau (ed.) MediaArtHistories (Cambridge, MA: The MIT Press), 402.

20 Kemény Zsigmond naplója (1974) Eds Margit Ács and Samu Benkő (Budapest: Magyar Helikon), 143.

21 Nagy, Miklós (1972) Kemény Zsigmond (Budapest: Gondolat), 53.

22 Barta, János op. cit., 77-89; Nagy, Miklós op. cit., 43-53; Szegedy-Maszák, Mihály op. cit., 86-90; Cooper, Thomas op. cit., 29-44.

23 Boehm, Gottfried (1995) 'Bildbeschreibung' in Beschreibungskunst-Kunstbeschreibung: Ekphrasis von der Antike bis zur Gegenwart (München: Fink), 23-41.

24 Péterfy, Jenő (1983) Válogatott müvei (Budapest: Szépirodalmi), 561.

25 Nagy, Miklós op. cit., 51.

26 Neumann, Gerhard and Oesterle, Günter (1999) 'Bild und Schrift in der Romantik' in Bild und Schrift in der Romantik (Würzburg: Königshausen \& Neumann), 9-23.

27 Novalis (Friedrich von Hardenberg) (1969) 'Aus dem «allgemeinen Brouillon»' in Werke Ed. Gerhard Schulz (München: C. H. Beck), 459.

28 Kulcsár Szabó, Ernő (1999) 'A fordítás «antihumanizmusa» mint az önmegértés új történeti alakzata' Alföld, No. 2, 51.

29 In reviewing Kemény's pamphlets on geopolitical questions after the Hungarian revolution of 1847-48 (After Revolution and Another Word After Revolution) Mihály Szegedy-Maszák discovered the basis for more professional studies in Kemény's excellent literary hermeneutics as well. Cf. Szegedy-Maszák, Mihály (2000) ‘Az újraértelmezés kényszere: Kemény Zsigmond két röpirata a forradalomról' Irodalomtörténet, No. 1, 3-14.

30 " $[\mathrm{H}] \mathrm{e}$ was an aestheticist on the world throne; deep in this tyrant's soul lay melancholy. Nero was a child who never grew up; his inner man, the spirit, never broke through; it gathered within him as anger, dread, anxiety [angst]. Although Emperor of Rome, he fears a bold look from a human being and has this person destroyed. Nero has no murder on his conscience, but his spirit has a fresh anxiety. Anxiety filled himself, he seeks to make others anxious. A riddle 
to himself, he wants to be a riddle to others and to delight in their anxiety. In the judge's great portrait of Nero, Kierkegaard has captured many traits which also apply to dictators of recent times.” Jansen, Billeskov Søren Kierkegaard: Life and Work http://www.sorenkierkegaard. nl/artikelen/Engels/014.\%20Kierkegaard\%20life\%20and\%20work.pdf

31 Schlegel, Friedrich (1980) 'Kritikai töredékek' in Válogatott esztétikai írások, Ed. Dénes Zoltai (Budapest: Gondolat), 220.

32 Papp, Ferenc (1922) Báró Kemény Zsigmond, I (Budapest: MTA), 59 ff.

33 Barta op. cit., 46.

34 The abovementioned Wackenroder owes great importance to recollection, too, as he speaks of "the hearts defecated in contemplation", to whom the "holy humility for the withered time" shows up the true image of the things more faithfully than the "frozening looks of the official critics". Wackenroder op. cit., 53.

35 Belting Image, Medium, Body..., 308.

36 Belting, Hans (2009) A hiteles kép: Képviták mint hitviták (Das echte Bild: Bildfragen als Glaubensfragen) (Budapest: Atlantisz), 237-41.

37 Almási, Miklós (2010) ‘A képvilág paradoxonai’ Mozgó Világ, No. 4, 103-5.

38 Ibid.

39 Eisemann, György (2007) 'Elhallgatás, beszéd, szubjektum Kemény Zsigmond regényeiben' Iskolakultúra, No. 1, 41-7.

40 "How come that a highly intelligent and experienced stateman becomes the slave of his immature but still debauched sovereign, a Seneca of Nero?" Nagy op. cit., 43.

41 Cf. Kamper, Dietmar (1994) Unmögliche Gegenwart: Zur Theorie der Phantasie (München: Fink), 71-95.

42 Thomas Cooper revealed a possible correlation between the moral and theological uneasiness of the Renaissance and Kemény's own historical time, constituting the cultural basis for the subversive poetic form of the novel. Cooper, op. cit.

43 "Who was the model of these terrible sins? Neither the chronicles nor the archives could give an answer to our question." (Vol. I, 97-8.)

44 Belting, Hans Image, Medium, Body..., 305.

45 Cf. De Bruyn, Ben 'The Anthropological Criticism of Wolfgang Iser and Hans Belting' Image\&Narrative (online), Issue 15. http://www.imageandnarrative.be/inarchive/iconoclasm/ iconoclasm.htm

46 Novalis 'Aus dem «allgemeinen Brouillon»'... op. cit., 460.

47 Kierkegaard, Søren (1885) Entweder-Oder: Ein Lebensfragment (Leipzig), 186-7.

48 Kemény, Zsigmond (1971) Élet és irodalom: Tanulmányok (Budapest: Szépirodalmi) 205.

49 Ibid.

50 Ricoeur, Paul (1990) 'Le soi et l'identité narrative' in Ricoeur Soi-même comme un autre (Paris: Seuil), 167-98.

51 Ibid.

52 Ricoeur, Paul (1974) 'The Question of the Subject: The Challenge of Semiology' in The Conflict of Interpretations: Essays in Hermeneutics tr. Kathleen McLaughlin (Evanston, IL: North-Western University Press), 264-5.

53 Péter Bényei discusses three cardinal points of the deep tragicity pervading Kemény’s world: 1. relativizating tendencies of modern societies, 2. tragical facticity arising from the mutual influence of the persons on each other, 3. the ontic experience of caducity. Bényei, Péter $A$ történelem ... op. cit., 252-9. 